\title{
ALLOTMENT KEEPING IN LJUBLJANA
}

\author{
ALEŠ SMREKAR \\ Anton Melik Geographical Institute \\ Scientific Research Centre of the Slovenian Academy of Sciences and Arts \\ Gosposka ulica 13, 1000 Ljubljana, Slovenia \\ E-mail: ales.smrekar@zrc-sazu.si
}

\begin{abstract}
:
This article introduces the issue of the planning of allotment gardening in the case of Ljubljana, Slovenia, as a self-supplying activity by which fresh vegetables are cultivated. Allotment gardening is an activity that involves just a small percentage of Ljubljana's population, those enthusiasts seeing this activity as more of a recreation and relaxation than a way of earning money. The city authorities are already anticipating that allotments will be eliminated from locations deemed unsuitable, holders then being offered alternatives in more appropriate locations. The appropriateness of these planned locations for allotments was evaluated in respect of whether key exclusion and attractiveness measures were complied with. We also determined the partial suitability of selected locations.
\end{abstract}

Keywords: allotment gardening and keeping, allotment gardener, leisure activity, protection of the environment, spatial planning, Ljubljana, Slovenia

\section{INTRODUCTION}

Nature was and still is a part of every city, whether its presence there is planned or spontaneous, a result of decisions taken or random development at a given location. Even the constant growth of today's cities cannot completely wipe out nature. Contemporary urban centres in fact have rather a lot of greenery, in city parks, in avenues planted with trees, in old gardens and green plots and in smaller allotments and even certain gardens on the rooftops of buildings. Nature in cities is represented, not only by the human species, but also by certain pioneer and special flora and fauna species which have managed to survive in built-up areas. This is also why, regardless of the ever-growing non-natural elements within a city, the fate of nature itself in the controlled city environment is very much in the hands of human beings.
The relationship between human beings and nature has come through to the present day in a tangible need to connect with the natural world. This need is pursued by each person individually. City people are mainly used to city green space, like parks and areas of greenery. The modelled city landscape, especially its green space as a whole or as an element of an individual region, are in an urban environment acknowledged as suitable for meeting people's every need as regards connecting with nature. Within these green areas, city people continuously search for new, even more direct contacts with nature, a fact that must be acknowledged widely, with emphasis put on patience and sympathy for diversity on the part of the city authorities and urban planners themselves (Simonetti 2000).

Allotment gardening is a multifunctional activity whose main aim is the growing of vegetables meeting a person's own needs and those of his/her own family. 
The allotments kept are not generally a constituent part of areas around the apartment buildings in which holders actually live. Almost by definition, an allotment is separated from neighbourhoods resided in. This type of gardening offers a kind of self-supply in food, inasmuch as that vegetables from allotments are rarely if ever intended for sale. An allotment is an area of land maintained for horticultural purposes, and . allotment keeping thus focuses on vegetables, only rarely on fields crops. Although some allotmentkeepers do indeed grow (small areas of) potatoes and even corn, allotment gardening is in essence "gardening", and needs to be associated more with vegetables than, in any sense, "agriculture" (Simoneti et al. 1997).

Allotment holders and keepers are city people who usually "go off" to allotment land somewhere in the city or on its outskirts, but mostly not very close to the housing estate in which they live. The allotment holder is renting a small area of what was mostly de facto farming land, normally forming part of a multi-holder gardening complex. It should be noted that some gardeners unite over their allotment-keeping land, in order to cut their costs, to achieve a higher level of safety and to help solve problems and come into contact with various experts.

Allotment-keeping is a natural element in the environment of all developed Western cities. While it is usual (certainly usual in free-market conditions) for cities to lack much free space, allotment areas are normally found in locations that are not interesting in regard to other activities. Such areas are: abandoned areas of former urban use, nearwater areas, areas under power lines, areas along roads and railroads and areas near apartment buildings. The biggest potential for further development of allotment gardening is thus represented by large public areas, which city authorities have declared (at the given time at least) as not intended for building. They are thus maintained as a reserve for further landscape shaping, the eventual growth of the city (Smit et al. 1996) or the preservation of groundwater resources. A genuine lack of space for allotments in urban areas remains a rare thing today, where they do exist relating more to the acquiring of all legal rights to use the land intended for allotments, this of course being a prerequisite for such land use. This is why all possibilities for choosing suitable locations have first to be examined. Then it is necessary to determine the conditions for legal use of land and, lastly, to give suggestions of how to grow and what to grow on allotments (Smit et al. 1996).

Allotment-keeping is in fact a rather complex activity which satisfies various needs (Vastl 2000):

- existential needs, with the possibility of conventional or organic production of food,

- physical needs with the possibility of recreation, relaxing and resting,

- health needs with the possibility of constant movement, unlike in the professional non-active work environment,

- social needs with the possibility of making personal contacts and

- psychological needs with the possibility of coming into contact with nature.

Allotment-keeping is evaluated in connection with social history, with its significance being looked for in economic or ecological production, as it is considered a source of burdens for the environment, as well as a possible way of dealing with degraded urban areas and as a way of addressing problems of physical and mental health, as well as providing possibilities for free-time relaxation and recreation. Some even see it as the fulfilment of a wish to "own" at least a small piece of land (Goriup 1984).

Healthy or "safe" food, health-compliant drinking water and the preservation of nature's resources are the most important factors of strategic significance when it comes to guaranteeing that people have suitable living conditions and a healthy environment while economic and social development as a whole becomes more sustainable. Regarding sensitive landscape, factors such as urbanisation, industrialisation, traffic and agriculture represent the main threats to the population's health and the sustainable treatment of nature's resources. 
The production of food in environmentally vulnerable alluvial plains and within a polluted environment can, due to irregular or excessive use of phytopharmaceutical agents and fertilizers, represent a great risk to people's health. People can be in danger directly, in the sense of eating polluted home-grown vegetables/products, or indirectly, through the polluted environment, mainly groundwater.

Allotment-keeping as it is defined today, first saw the light of day on the planned small gardens across Europe in the second half of the 19th century. Allotments were mainly designed with a view to city people relaxing, while at the same time doing something useful. It thus fit within the $19^{\text {th }}$ century current of interest in socio-economic, health-related and political issues. The number of allotments rose more quickly in times of crisis, due to the "supplying role« of allotments being more important then.

The pioneer of organized allotment-keeping was the German doctor and orthopedist Daniel Gottlieb Schreber (1808-1860) of Leipzig. Schreber suggested to the boards of directors of factories that they might rent out small pieces of land to their workers, allowing them to garden in their own allotment.

The idea and actual practice of allotmentkeeping spread all over Germany, as well as into Belgium, France and certain other countries. Cities and their open areas came to have allotments with slightly more varied functions, and under such names as Schreber's gardens, workers' gardens and garden colonies.

During WWI, allotment-keeping became even more popular, due to the constant needs for whole city populations to become fully or semi self-supplying. The practice continued to expand in the period between the Wars, to achieve a true blossoming in The Netherlands, the UK and Switzerland. After WWII, the habit expanded yet further in both Western and Eastern Europe.

In the case of Slovenia, gardening for the purpose of the sale of vegetables and meeting individuals' own nutritional needs spread greatly at the beginning of the 20th century (Vastl 2000).
Up to the end of WWII there were two key motives underpinning the spread of the practice of allotment-keeping:

- a desire to in some sense offset insufficient areas for living in by assigning private open space to people,

- a desire to have the socially weaker classes meet minimum living standards through their growing of vegetables and fruit and their raising of small livestock.

After WWII, the motives for allotmentholding changed considerably. The role in growing food to meet a person's own needs tended to decline in most cases, while the importance of gardening as a means of recreation and relaxation grew - a factor also reflected in the trends regarding the erection of sheds.

It is probably in Germany and The Netherlands that allotment-holding is most fully developed. There are more than 1,300,000 individual allotments in place in Germany, the total area exceeding $460 \mathrm{~km}^{2}$ (Zimbler 2001). In 2006 Berlin had more than 76,000 allotments, which extended over an area of more than $31 \mathrm{~km}^{2}$, or around $5 \%$ of the entire area of the city (Daten und Fakten 2009). The German government started with legal "protection" of allotments at an early stage. The first piece of law, the so called "Act on allotments and leasing plots", was passed as early as in 1919. In 1983, this Act was supplemented and changed into a "Federal Act on allotment-keeping", which is still in force, albeit supplemented in 2006. The Federal Act lays down rules for the protection of allotment areas, for preserving their long-term leases as established among local authorities and allotment associations, and for the removal of allotments and their replacement with substitute land elsewhere. The Act also determines the price at which an allotment can be leased. Germany is the first country to define allotment-keeping as an activity of sustainable land usage, including a definition of this kind in its spatial legislation.

Plot gardening in The Netherlands was established on the basis of the German model. The data at hand show that there are around 240,000 allotments in The Netherlands, with 
5,995 of them located in the Amsterdam area. They comprise an area of more than $2.8 \mathrm{~km}^{2}$ and are part of 29 allotment associations (Bond van volkstuinders 2009). As in Germany, various government agencies are in charge of managing allotment areas. They lease the land to local societies, which then lease individual allotments to those interested. The Netherlands has an umbrella act on allotment-holding, which ensures the protection of allotments, although this act has not yet been passed officially. Therefore the role of allotment areas, as an important element of urban land use, is defined by the country's spatial policies.

The basic research hypothesis is that in Ljubljana allotment-keeping is randomly dispersed, as it can, in many cases, be found to take place in unsuitable locations. The main goals are the following:

- to define the spatial and temporal distribution of allotment areas

- to define the structure of allotments as well as their holders

- to evaluate the suitability of suggested new locations for allotments.

\section{METHODS}

We (Jamnik et al. 2009) compiled a questionnaire with which we sought answers to some basic questions about allotment-keeping, as well as many details connected with it. The questionnaire comprises 150 questions with a great many sub-questions. The questions were meant to be quite direct with many logical sub-questions capable of leading to quality answers. The questionnaire is formed by the following content groups:

- socio-economic indicators,

- living conditions,

- motives for allotment-holding and keeping,

- relations concerning land-ownership and rental,

- infrastructure available on the allotment,

- vegetables (crops),

- relations towards the environment,

- relations towards the soil,
- relations towards groundwater

- knowledge of water-protection areas

- time and quantity of use of fertilizers,

- time and quantity of use of phytopharmaceutical agents,

- knowledge of allotment-keeping

- further plans and expectations concerning allotment-keeping.

In the year 2005, 302 surveys were carried out in 34 allotment areas serving as a representative sample.

Areas with allotments that were part of the survey were chosen on the basis of:

- location as regards water-protection areas,

- type of soil,

- location of potential pollution sources,

- size

- the most even distribution.

A synthesis of survey answers was also made, with certain survey questions compared with other sources.

The suitability criteria for suggested allotment areas from the draft part of the spatial plan of the City Municipality of Ljubljana (Minister na slovesnosti ob podelitvi ...) have been determined on the basis of survey results and expert evaluations. They can be divided into two groups, namely exclusion and attractiveness criteria.

With the help of exclusion criteria we checked if there are any locations among the suggested allotment areas that are, for reasons legislative, urban-planning-related, health-related or environmental, completely inadequate. Among these the most vulnerable are narrow water-protection areas, locations within the historic city centre and locations in the immediate vicinity of water sources, waste dumping areas and major traffic routes. All these factors can have an effect on the quality of produced vegetables. Exclusion factors represent the minimum which should be met by all new locations, seeing that they are determined on the basis of expert evaluations and legal norms (Jamnik et al. 2009).

The attractiveness-criteria determined 
the potential attractiveness of an area for allotment-keepers. They are of great importance as the conditions on the suggested allotment locations should be agreed with users, as well as the community as such. If allotments are established in areas which are inadequate from the point of view of users, the formation of new illegal allotments more adequate for users can result.
These criteria were established on the basis of surveys given out to allotment-keepers, with emphasis put on some location factors where the importance of some answers was concerned. Some allotment-keepers for example named accessibility of the area as one of the most important factors $(66 \%$ thought it most important). The majority $(82 \%)$ of those surveyed said that the rea-

Table 1. Set of exclusion criteria and attractiveness criteria as regards contribution to the comprehensive evaluation of attractiveness.

combined proportion regarding the evaluation of attractiveness

\section{I. exclusion criteria}

1. outside the city centre

2. outside the largest water-protection zone (1)

3. outside the narrowest zone of water sources $(50 \mathrm{~m})$

4. outside the narrowest zone of forests and waste dumping grounds (100m)

5. outside the narrowest zone of traffic routes (highway 100m, local road $30 \mathrm{~m}$, railroad $30 \mathrm{~m}$ )

\section{II. attractiveness criteria}

\section{1. accessibility, infrastructure}

A distance from apartment building

B distance to the nearest bus stop

C municipal infrastructure - sewer system, water distribution system

D distance to water sources

\section{2. health, fertility}

A soil suitability for allotment-keeping

B distance from major traffic routes

C distance from industrial buildings

D distance from other intensive activities (shopping centre, business zone...)

\section{3. impacts on the environment}

together $5 \%$

A suitable distance from built-up areas (up to 200m)

B narrowest and wider water-protection zone (IIA, IIB, III)

$2.5 \%$ 
sonable distance to a allotment garden was up to $5 \mathrm{~km}$, which agrees with the current situation. $83 \%$ of all allotment-keepers have less than five kilometres to travel from their home to their plot. Based on survey results, allotment-keepers are against even worse accessibility of allotments - a fact that should be taken into consideration when planning new locations for this activity. Also among the most important factors are soil fertility and remoteness from major traffic routes, while among the less important factors we find common landscape attractiveness, including the closeness of forests and rivers, as well as social factors and quietness.

Accessibility indicators were determined on the basis of survey results, also taking into consideration the proximity of public bus stops, as public transport plays an important role in the spatial plan of Ljubljana. As a less important factor the survey determined access to water sources, which meant that we considerably lowered its significance when determining the comprehensive suitability of an area.

Among the attractiveness-criteria for allotment-keepers, there are also some connected with the issue of health and with soil fertility. According to the survey, the matter of the greatest importance is soil suitability, only to a lesser extent the remoteness from some main polluters, these being major traffic routes, industrial areas and other intensive activities.

Among the latter we included shopping centres, whose effect is to contribute to strong traffic currents. Regarding traffic routes we took into consideration state routes of higher categories or rather highways, motorways, local roads and railroads. Soil suitability is evaluated on the basis of organic matter content and suspected contamination with heavy metals, as well as depth and texture.

The last group of attractiveness-criteria, making the smallest contribution to the comprehensive evaluation included »impacts on the environment« Its meaning is based on expert evaluations and it contains two factors which influence the general state of the environment. The vis- ual perspective demands that allotmentkeeping is relatively distant from built-up areas and areas where building is planned for the future. A small portion of the evaluation of attractiveness is represented by a location in water-protection areas, as gardens should haveno negative effects on the quality of groundwater.

\section{MAIN CHARACTERISTICS OF THE STUDIED AREA}

Ljubljana is a city nestled between Ljubljansko Polje to the north and Ljubljansko Barje to the south. The city was established right in the heart of Ljubljana basin, on the passageway between Polhograjsko Hribovje in the west and Posavsko Hribovje in the east. Ljubljana extends over a narrow area due to the narrowness of the Sava basin (Jernej 2000). Ljubljana's basin hinterland is marked by two rivers, the Sava and the Ljubljanica and along both rivers extend the areas of Ljubljansko Polje and Ljubljansko Barje with large amounts of groundwater.

Data on the distribution of allotments in Ljubljana go back for the few last decades only (Goriup 1984, Simoneti et al. 1997; DOF 2005). It is interesting to see how the significance of allotment-keeping continued to change in different periods. This is clearly seen in the combined area of allotments, as well as the numbers of people in Ljubljana in any way connected to this activity.

In 1984, when allotment-keeping was quite widespread in Ljubljana, allotments in 289 areas combined occupied exactly 2 square kilometres of land which equals 200 hectares. Allotments are in different locations very dispersed over the flatter parts of Ljubljana. They normally appeared in some less attractive areas, for example along the fences of industrial and business parts of the city, along railway tracks and roads, in building areas which were not sufficiently used, between apartment buildings, etc. They could also be found in some areas with public greenery, along rivers and streams and among agricultural land. 
Table 2. The transformation of Ljubljana's allotment areas and the number of allotments between 1984 and 2008 (Goriup 1984; Simoneti et al. 1997; DOF 2005; Jamnik et al. 2009).

\begin{tabular}{lcccc}
\hline year & 1984 & 1995 & 2005 & 2008 \\
\hline surface $\left(\mathrm{km}^{2}\right)$ & 2.00 & 2.67 & 1.86 & 1.30 \\
number of areas & 289 & 378 & 249 & 218 \\
\hline
\end{tabular}

The next decade saw extensive growth of allotment areas, in terms of both size and number. Their overall area grew by about a third and was 2.67 square kilometres (267 hectares) in 1995, with the number of areas with allotments growing by something less than a third, to 378 all together. The largest new and widely spread areas erupted out along the highway ring of Ljubljana. A dropping of agricultural activity in the 1990s was also seen in allotment -keeping, as many new gardens started to appear on abandoned fields. In some built-up areas of the city with a high density of buildings, new buildings did take the place of allotments.
Up to 2005, the number of allotmentkeepers fell, due to the new and more urbane way of living which also resulted in lesser connectivity between people and the land. We were not therefore surprised by the statement that, between 1995 and 2005, the overall area of allotments declined almost 30 percent (down to $1.86 \mathrm{~km}^{2} / 186 \mathrm{ha}$ ), with the number of allotment areas being reduced by almost 35 percent.

Active intervention of the city authorities also contributed to the reduction in allotment areas up to the end of 2008, to as few as 218 , with the overall surface area being reduced to just $1.30 \mathrm{~km}^{2}$, i.e. by a third (Jamnik et al. 2009).

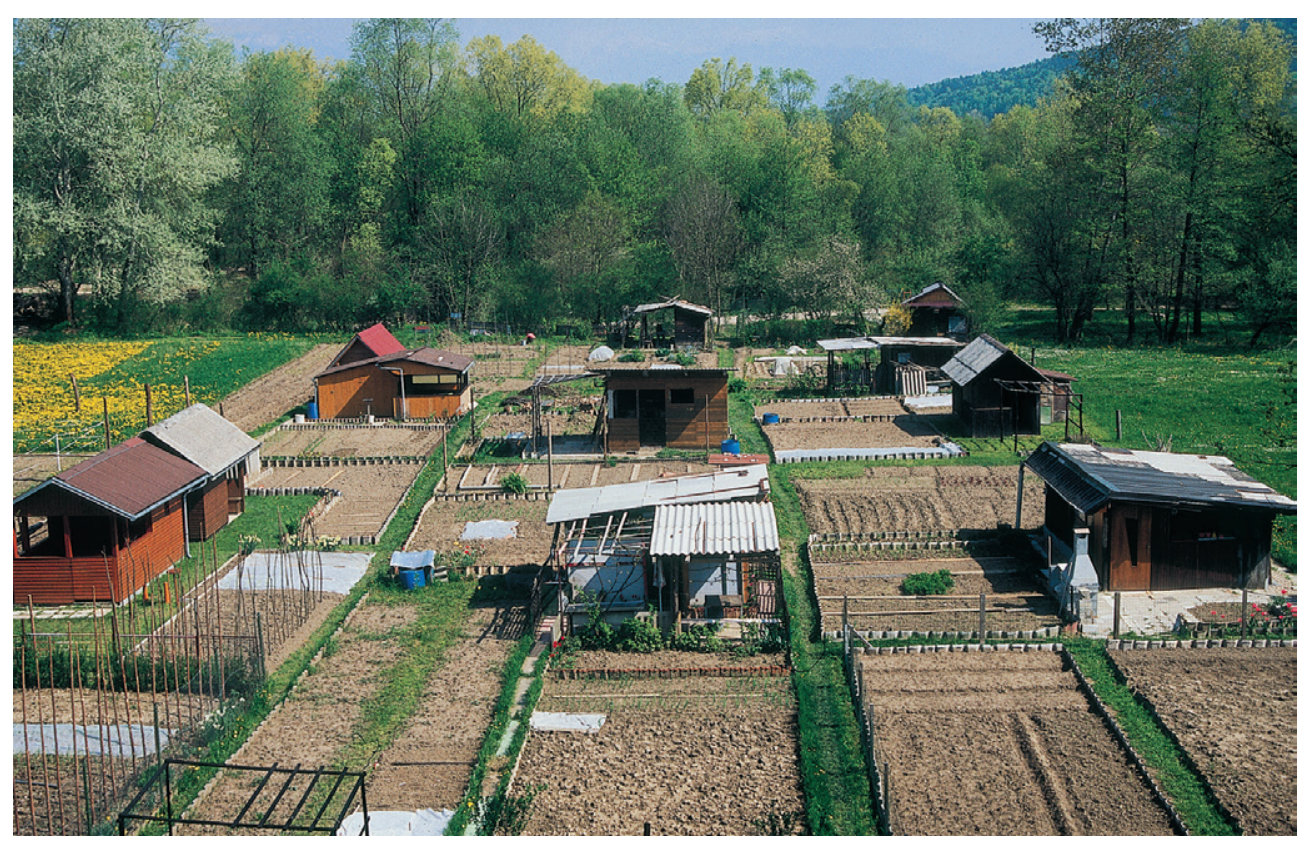

Figure 1. A typical allotment area in Ljubljana. 


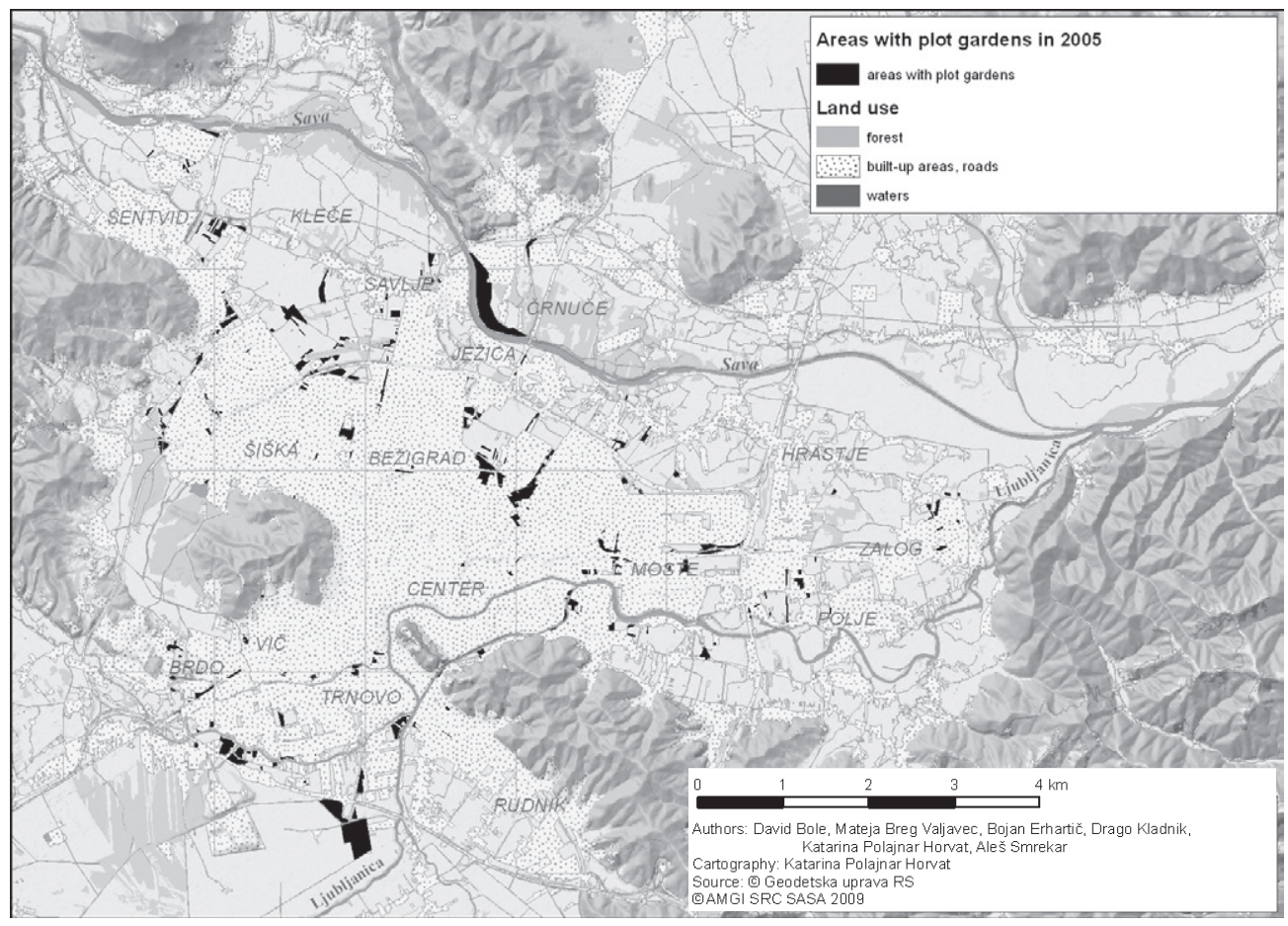

Figure 2. Allotment areas in Ljubljana in 2005.

\subsection{ALLOTMENTS}

Allotment areas are of different size, ranging from a few tens of $\mathrm{m}^{2}$ to some 10 ha. Allotment-keepers usually rent land, with only $7 \%$ of them enjoying rights ofownership. Among $93 \%$ of renters less than half (43\%) pay rent for the land they work on, all the rest (half of all gardeners who were part of the survey) use the so called »no man's land «, for which they do not pay any rent. As many as three-quarters of allotment-keepers do not have a signed rent contract. $91 \%$ of them said that they did not want to rent any additional land for cultivating or even expanding of their allotment-holding activity. Only a third of them wish to buy their land.

The phenomenon of allotment-keeping in Ljubljana is not based solely on the economic component, being mainly about food production - as evidenced by the fact that many $(28.5 \%$ of $)$ allotments also include an ornamental garden and ornamental grass $(26.5 \%)$. A surprising number $(26 \%)$ of allotment-keepers have a "plantation of fruit trees « and even a vineyard, or at least a trellis for vines $(20 \%)$.

We established (Jamnik et al. 2009) that the average size of allotments in Ljubljana in 2005 was $205 \mathrm{~m}^{2}$, with almost half of the land $\left(101 \mathrm{~m}^{2}\right)$ being used to grow vegetables. Quite a large portion of the land was used as a yard (over a fourth of the average land area $\left.-55 \mathrm{~m}^{2}\right)$.

The infrastructural capacity of allotment areas is relatively limited. The majority of them (235) are accessible via driveways, which are insufficiently taken care of and not made adequately. Connected to the public water system are just $15 \%$ of all allotment areas, with electricity available in some only.

Only a handful of allotments have shared buildings. Some have in-common lavatories (12) and waste containers (14.) 


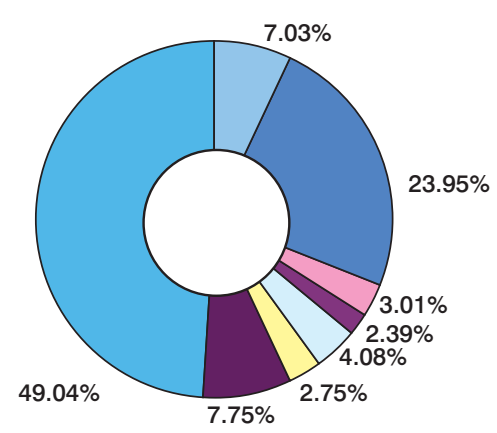

$\square$ Vegetable garden
$\square$ Orchard
$\square$ Vineyard
$\square$ Ornamental grass
$\square$ Ornamental garden
$\square$ Paved yard
$\square$ Unpaved yard
$\square$ object

Figure 3. The percentage of land intended for specific land use.

Unlike in the case of allotment areas in Austria (as was established during field work in Vienna and Graz), Germany or Switzerland (Christl et al. 2004) Ljubljana's allotments are not enclosed within fences. But many allotment-keepers (114 or $38 \%$ ) have protected or delimited their »own « land in some way, mostly with stone walls (38), rarely with fences of barbed wire (30), hedges (29) or wooden fences (14).

Two thirds of allotments have a building of some sort (Jamnik et al. 2009). The average size of this building is $14 \mathrm{~m}^{2}$ and takes around $7 \%$ of the land overall. These objects (buildings) were built without any plans, randomly and out of various materials. They are like some emergency sheds, which have a negative effect on the attractiveness of the whole area. In many cases these are not regular sheds for keeping tools and products, but more like small holiday houses. Wood is mainly used, as more than $93 \%$ of all objects are wooden. The rest are mainly made of sheet metals. What is often worrying is that the predominant roof covering is asbestos (in as many as $64 \%$ of cases). Although the majority of cancer-threatening asbestos roofs in Slovenia have already been replaced, it is easy to conclude that allotment-keepers feel they have no a real interest in replacing their dangerous roofs.

\subsection{ALLOTMENT-HOLDERS}

First renters of smaller pieces of land in Ljubljana date back to the beginning of the 20th century, when they started to cultivate smaller plots and grow vegetables (Vastl 2000). They can be seen as the pioneers of allotment-keeping in Ljubljana. In their further development up to the end of WWII two motives played the most major role:

- supplementation of insufficient apartment areas with private open spaces

- helping the socially weaker classes attain minimum standards of living through the growing of vegetables and fruit and the keeping of small livestock.

After WWII the motives for allotmentkeeping changed quite drastically. The function of food supply lost its importance, while the functions of relaxation and recreation gained in importance.

Allotment-keeping is an activity involving only a few percent of Ljubljana's population. The exact number is unknown, but the rough estimate, made a decade ago (Simoneti et al. 1997) - was that this involved about 12,000 inhabitants of Ljubljana in the 1990s (the more exact number should be around 13,500 people). Seeing that the year 2005 saw quite a substantial reduction in the area with allotments, we can with certainty say that the current number of allotment gardeners in Ljubljana is below 10,000 (Jamnik et al. 2009).

A reduction in the number of allotmentkeepers does not mean that the need for this activity is markedly lower, seeing that this is an activity which continues from generation to generation. A 1980s survey (Goriup 1984) confirms this, noting how $88.6 \%$ of allotment holders grew up in families which had a garden at home. Among allotment gardeners there are 
many who moved to the city, but clearly had a specific connection with the environment (in this case a garden). The same survey also confirms a somewhat surprising stability and persistence within the grouping of allotment gardeners. Only one in six of them eventually dropped their activity, primarily for reasons of illness or related problems.

The survey (Jamnik et al. 2009) included 302 allotment-keepers, within an overall sample size of 551 people. The typical allotment in Ljubljana is regularly visited by two people - in most cases partners (54\%). Slightly over one-third $(33.8 \%)$ of all allotments are visited by just one person. Only $8.3 \%$ of allotments are taken care of by three people. On average allotment-keepers spend an hour and a half on their gardening per day, as opposed to the two or three hours mentioned by Goriup (1984). This reduction in the amount of free time available for allotments reflects more restrictive working conditions, these in turn reflecting wider contemporary sociopolitical change.

There are slightly more women than men among the allotment-keepers (54.1 to $45.9 \%$ ), this most certainly reflecting greater female life expectancy. Allotment gardening is the domain of older people, a fact confirmed by the average age of allotmentkeepers in Ljubljana - 60.6 years (Jamnik et al. 2009). By comparison, the average age of an allotment-keeper in Zürich is 61 (Christl et al. 2004).

The educational level of allotment-holders is below average for Ljubljana as a whole (Jamnik et al. 2009). The difference is visible where those with tertiary education are concerned (no fewer than $24 / 2 \%$ of the people of Ljubljana, as compared with just $11.8 \%$ of allotment gardeners. The latter figure is nevertheless perhaps higher than might have been expected, suggesting that allotment-keeping may be an important aspect in the rest and recreation enjoyed by the well-educated. Indeed, among the other three categories of educational attainment, differences are barely visible. $38.1 \%$ of allotment gardeners came successfully through highschool (cf. 33.1\% overall in Ljubljana), $23.4 \%$ completed a 2 - or 3-year programme of studies at vocational school (cf. 21.0\% in Ljubljana), and 23.8\% had at best primary education (cf. $21.5 \%$ in Ljubljana).

The trend for the proportion of Ljubljana allotment-kepers that have tertiary education may be slightly downward, seeing that the percentage two decades ago was $12.6 \%$ (Goriup 1984). This interpretation calls for discretion, as the rise in the education level in Slovenia over the past two decades is quite striking. This suggests that the role of allotment gardening among those with tertiary education is not actually diminishing, as expected, but is in fact more and more significant.

Around half (53.4\%) of allotment-keepers in Ljubljana are retired and a third (32.8\%) are employed. The percentages accounted for by other groups are markedly lower. Relatively large is the percentage of unemployed allotment-holders $(5.6 \%)$, though this is in line with the percentage of inhabitants of Ljubljana that are unemployed (Jamnik et al. 2009).

Plot gardening is a way for city people to spend free time, this reflecting a sense of confinement in apartment buildings packed together in really small areas that make other gardening impossible (in the so-called green areas around apartment buildings). These people see allotment-keeping as their retreat into to nature, to a place where they can be free and are not limited by the four walls of their apartments. Among all those taking part in the survey, almost three-fifths $(59.3 \%)$ of all allotment-keepers come from areas with large apartment buildings, in which they consider they are not able to »live their lives « to the fullest.

Less than a quarter $(22.8 \%)$ of allotmentkeepers live in apartment buildings which are not densely packed. $8.6 \%$ live in houses, with $7.9 \%$ of allotment-keepers living in apartment buildings of less than five flats (Jamnik et al. 2009).

The majority of allotments are close to the homes of their owners, this making daily visits possible, especially as the majority of allotment-keepers are retirees, or else un- 


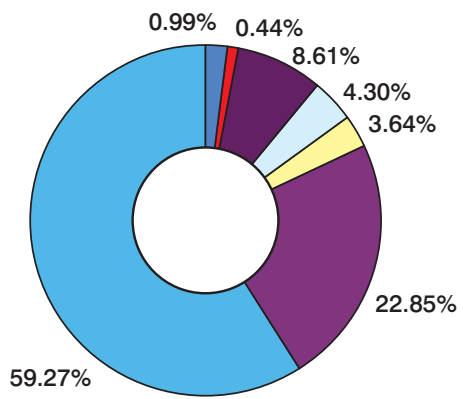

Apartment building or a multistorey building with a high object density

Apartment building or a multistorey building with a low object density

Residential building with up to 4 flats with a high object density

Residential building with up to 4 flats with a low object density

House

Plot-gardening object

No data available

Figure 4. The type of living unit in which members of allotment-holding households live.

employed. More than two-fifths (42.1\%) of allotments are less than a kilometre away from the home of a typical allotment-keeper. Around $40 \%$ of allotments are within walking distance ( 1 to 5 kilometres) of the residence of a typical allotment-keeper, which is still relatively close. Some allotment-keepers are willing to cover greater distances $-5.3 \%$ even have allotments more than 10 kilometres from their homes.

Those surveyed (Jamnik et al. 2009) defined allotment-keeping as a means of relaxing and recreation (29\%), finding the necessary connection with nature $(22 \%)$, physical activity $(20 \%)$, or a means for producing healthy foods themselves $(20 \%)$. It is interesting that less than a tenth $(9 \%)$ of people surveyed see allotment-keeping as a means of producing foods for mere existential reasons.

Among the predominant problems for allotment-keepers are polluted vegetables along traffic routes and the damage which is done to their plots by people walking by and littering. Respondents are also bothered by the damage wild animals do, the lack of water resources nearby, the noise coming from nearby highways, railroads and factories, as well as the smell from nearby waste dumping grounds and the lack of infrastructure. Some are bothered by the look of allotments themselves. Other reasons are damage done to buildings put up in allotments, vandalism, partying on allotments, dogs parading over neatly prepared gardens, waste accumulation, inadequate use of insecticides, inadequate parking solutions and unsuitable access due to inadequate routes, and the remoteness of allotment areas in regards to their neighbourhoods, which in turn connects with heavy traffic and the lesser mobility of older allotment-keepers. They are even bothered by that common Slovene "virtue«, envy.

\subsection{THE »ALLOTMENT WAR«AND THE STRIVING TOWARDS PLANNED AND CONTROLLED ALLOTMENT-KEEPING}

In spite of many efforts to reduce the negative influences of allotment-keeping, the last few years have seen random interventions by city authorities in some allotment areas. Commencing in April 2007, the "allotment war" (as the media dubbed the quarrel between the mayor of Ljubljana and allotment-holders) was associated with insufficient expert opinions and old laws (from the mid 80s) to offer a basis for such actions. The conflict with allotment-keepers broke out in the area of Ljubljana's cemetery, Žale, where the prevailing opinion was that hutments should not be part of the immediate vicinity of such cultural heritage of European importance, which is represented by Plečnik's architectural works in Žale (Minister na slovesnosti ob podelitvi ...). Reasons for their removal are not to be found in the neglected outlook of some of allotment complexes, but rather in the fact that many inhabitants cultivated the land which was owned by the City Municipality of Ljubljana and did not even pay rent for it. 


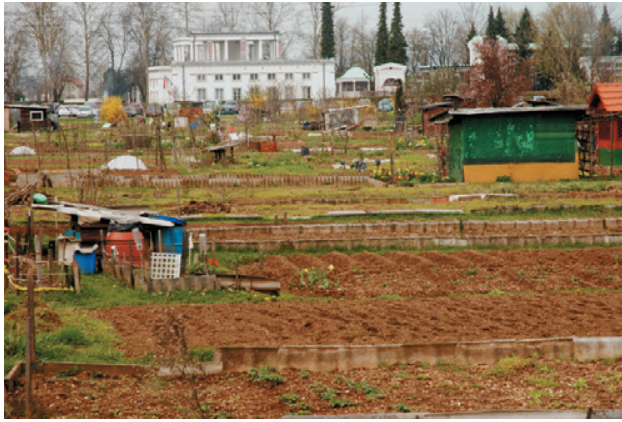

Figure 5. An allotment complex in the vicinity of a cultural monument (in the background) before removal.

With the removal of some disputed allotment areas, the city authorities began to pursue certain measures whose goal would be to reduce the current randomly-distributed allotment activity over the current $1.30 \mathrm{~km}^{2}$ area to a more modest (but fully furnished with infrastructure) $0.55 \mathrm{~km}^{2}$ of planned allotment areas.

An additional reason for planned and controlled activity in allotment-keeping (besides the need for a human- regulated environment along major roads entering the city at the time when Slovenia was holding the rotating presidence of the EU in the first half of 2008), was the finding that there are many wells and bores in allotment areas which are intended for watering these gardens. There should be around 400 such wells and bores just in the allotment area on the left bank of the river Sava south of Črnuče (Smrekar and Kladnik 2007). There they started the removal of allotment objects in the autumn of 2008.

Allotment-keepers who chose the left bank of the river Sava to establish a pseudosettlement with streets and even home-made house numbers, were called upon the city authorities to remove their objects themselves, if not, this would be done by city authorities at the expense of allotment gardeners. After some harsh words and police intervention, all illegal objects were removed.

The recently suggested 'Decree draft on the regulation and lease of allotments for rent'

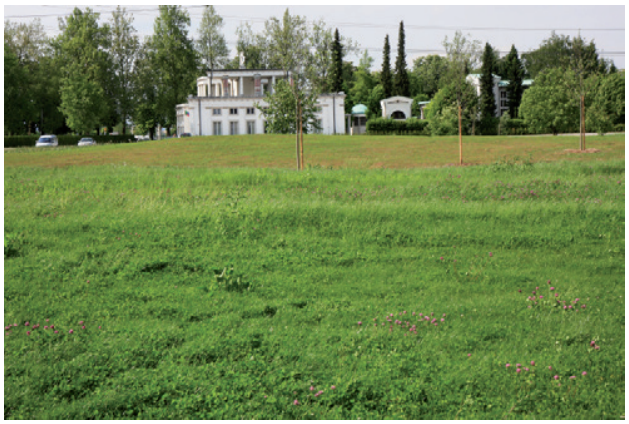

Figure 6. An allotment complex in the vicinity of a cultural monument (in the background) after its transformation into a park.

pays special attention to the protection of the environment. For this reason only rainwater should be used in watering gardens (Dopolnjen osnutek Strateškega ...). The Decree should prevent allotments from disrupting Ljubljana's image and prevent building of neighbourhoods with real weekend-houses, this certainly not being the main aim of allotment gardening. As the Draft of the decree states, the City Municipality of Ljubljana will rent out land in some temporary or lasting locations, with a view to encouraging the activity of allotment-keeping. Nowadays allotments are defined as special city green areas, which are not located in the narrowest waterprotection zones, in the city centre and in more exposed locations, which could hurt the image of Ljubljana as a whole. In the future allotments will not be found in the vicinity of cultural monuments and cemeteries.

\section{SUITABILITY EVALUATION OF LOCATIONS OF ALLOTMENT AREAS AS DEFINED IN THE DRAFT OF THE SPATIAL PLAN BEING IMPLEMENTED FOR THE CITY MUNICIPALITY OF LJUBLJANA}

The suitability estimation of planned allotment areas in Ljubljana was made on the basis of two aspects, i.e. expert judgments and the wishes of users (allotmentholders). 
We first checked all the suggested locations for allotments to assess their compliance with exclusion criteria. All five criteria markers were in fact met by locations outside the city centre, these being sufficiently distant from major traffic routes, water sources, waste dumping areas, forests and the closest water-protection areas. Adequate distance from major water sources was, however, somewhat conflicting in respect of two locations, where more than a tenth of the allotment area is within 50 metres of the bordering stripe. We thus establish traffic routes as the most important exclusion criterion, in that four of the suggested areas failed to meet this criterion in full.

The map marks some locations for allotments that are either entirely inadequate (in that they fail to meet one criterin or more), oronly partly adequate, in that the said criteria are met in some manner only, but not completely $(90 \%$ of all allotment areas are outside the borders, with only $10 \%$ within). Completely inadequate are three areas failing to meet the criterion of suitable remoteness from major traffic routes. Two areas are only partly adequate, as they do not fully meet the criterion regarding suitable remoteness from major water sources.

In the second phase we checked the criteria of accessibility and infrastructure, health and fertility, as well as impacts on the environment. These all come under the heading of attractiveness criteria, using the expectations of allotment-keepers themselves, plus scientific evaluation, with a view to establishing which of the planned areas for allotments is most suitable. In respect of the less suitable areas in particular, a new evaluation of location suitability by those in charge of the spatial plan seems to be in order.

Satisfactory spatial accessibility is the most important factor underpinning the »attractiveness « of individual allotments.

In line with the fact that the majority of allotment-holders are actually people living in large estates with apartment buildings, we checked the average distance from these neighbourhoods to the suggested allotments. We then digitized these neighbourhoods on the basis of previous morphological analysis (Rebernik 2000). A further important observation would be that the accessibility of allotment areas is generally adequate, with two exceptions. Accessibility as regards public transport is somewhat worse, especially in the northern part. Areas there are also below average in regard to some basic infrastructural demands pertaining to the water distribution system and the sewer system. This means that some intervention in nature is needed in these areas.

An important criterion for the evaluation of the suitability of suggested allotment areas concerns soil quality. For the purpose of food production the soil must be fertile and should not contain any harmful substances, at least not in amounts that would be harmful in vegetables grown there.

If vegetables grown in this manner are without any plant diseases, they are of satisfactory quality, and healthy for people. The term adequately fertile also implies that the soil does not contain excessive nutrients, as their presence in greater amounts can result in more limited plant growth and in many physiological diseases. From the environmental perspective the soil is of quality when it adequately manages to sustain water and is in some measure permeable, but is at the same time deep enough to prevent possible negative consequences of the irregular use of phytopharmaceutical agents and overdoses of fertilisers and nutrients. Therefore the ground should not be too shallow or have a sandy texture (Jamnik et al. 2009).

Major indicators of soil quality regarding allotment-keeping are the content of organic matter, ground depth, ground texture and its level of contamination with heavy metals. Also to be acknowledged as a factor underpinning quality is the degree of contamination with very persistent organic pollutants (PCBs, polyaromatic hydrocarbons, etc.). Periods of contamination with active substances from phytopharmaceutical agents are (especially with the current level of phytopharmaceutical development), rather short, in that these are rapidly decomposed under the influence of the sun, water and microorganisms, and ongoing 


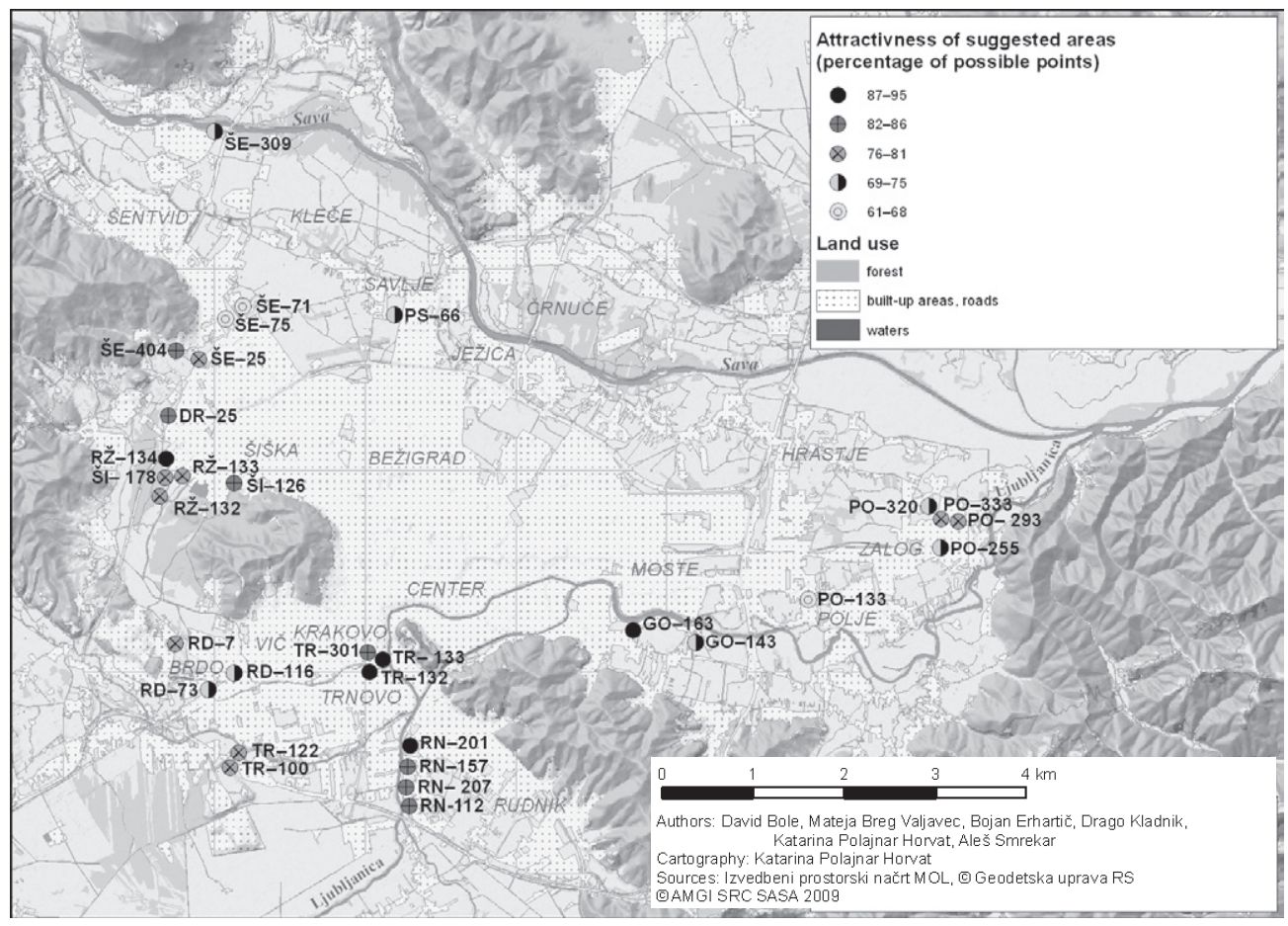

Figure 7. Results of the grading of foreseen allotment areas in respect of attractiveness criteria.

chemical processes within the ground. The content of less persistent active substances from phytopharmaceutical agents in garden soil in fact lowers considerably in the time between sampling and the completion of the analytical procedure in a laboratory.

The soils in the suggested allotment areas in Ljubljana can thus be defined as suitable and very suitable. Suitability can be seen to characterise allotments in non-polluted locations, while very suitable allotments are those with deeper soils in the north-eastern, western and southern parts of the city. However, traditional locations in the southern part of the city centre, in Krakovo (notwithstanding the fact that that area of garden plots is defined as Ljubljana's cultural heritage), are acknowledged as unsuitable or less suitable in regard to their soil quality, and specifically the content of pollutants.

When it comes to the health of allotmentkeepers, consideration must also be given to the factor of remoteness from major traffic routes. Seeing that allotment-keepers grow vegetables for their own needs mainly, they see closeness of traffic routes and highways as a negative factor. The majority of the suggested allotment areas are located far away enough from major traffic routes, though there are two exceptions, namely two areas in the immediate vicinity of the main city railroad and traffic routes. Regarding remoteness from industrial buildings only one allotment area is located inadequately.

When ascertaining the suitability of a specific area the least emphasis is put on the impacts on the environment, seeing that allotments do not normally influence nature negatively. The same is also true of the aesthetic aspect, but only if allotment areas are adequately located within the natural surroundings.

Then overall synthetic evaluations, made on the basis of attractiveness-criteria, were 
quite favourable for the planned allotment areas, since all the suggested locations achieved more than half of the 33 points possible.

Nevertheless some differences are apparent - due to relative proximity to major traffic routes and unsuitable soil, three of the suggested areas came out worse. Seeing that these two criteria together contributed to more than a third of the overall evaluation, the evaluation of all three mentioned allotment areas is lowered markedly (Jamnik et al. 2009).

\section{CONCLUSIONS}

"The joy of seeing your own work pay off, seeing and admiring a tomato growing. It is as if one was admiring the growth of love right in front of one's eyes."

plot gardener Bojan

In the context of the city, allotment-keeping is seen as a relic of the past, or of a rural way of life - as something unsuitable and temporary. In the best-case scenario, it is however seen as a constructive means of recreation that also contributes to the aesthetic look of the city. We see it as an important economic activity with a great growth potential, which represents major economic and mainly nutritional security for city inhabitants (Simoneti et al. 1997). Allotment-keeping is usually associated with certain stereotypes that do not give the activity quite the role which has been established on the basis of surveys and some current indicators. Allotment-keeping is an activity which should be taken seriously, as it is able to cover all the costs of its existence itself, even though it does not represent any real competitive threat to agriculture as such. In a suitable environment and with adequate instructions this activity is in no way harmful for the environment and does not give rise to any negative consequences, as for example informal land use or visible signs of illegal building / building without any authorisation or plan (Simoneti et al. 1997).

Because in the past Ljubljana's allotment areas were mainly established without any planning or control, it is no surprise that existing areas are sometimes present where they do not belong. Today's spatial planners, as well as some in the past, who had enough knowledge and information and were sufficiently environmentally aware, would not place some allotment areas in places in which they can be found today.

In Europe allotment-keeping is managed most extensively, and from the point of view of the law effectively, in Germany. In comparison with the spontaneously distributed and disorganized allotment areas in Ljubljana, German and Austrian counterparts are better organized and systematically included within city spatial plans.

Compared to Ljubljana's allotments, those in Germany and Austria only rarely represent a way of spending free time. For most people allotment-keeping is just a way of spending some »quality time« in nature among city buildings, a feeling of country life being imparted in this way. As we move southwards, closer to the Slovenian border, we can see that more and more allotmentkeepers do cultivate fresh vegetables, with the percentage of the land used for allotments also increasing. In the vicinity of Graz, allotments are quite similar to those in Slovenia, although they are organized to a much higher degree.

Ljubljana's allotments can be compared to those in The Netherlands, where allotment-keeping in many places is not as fully managed as it might be, in some cases even approaching the chaotic. Dutch allotments are mainly located on the outskirts of larger cities, in the vicinity of motorways and railways. We should point out that there are visible differences among allotment areas across The Netherlands. Some are extremely well organized (resembling those in Vienna in this respect), while others are not as organized and quite comparable to those in Ljubljana. Compared to allotments in Germany and Austria, the Dutch ones display a more intense focus on the cultivating of fresh vegetables. Objects in allotment areas are built in the similar kind of way as in Slovenia, whereas Slovenian allotments are 
more disorganized and not unified. Within allotment areas there are usually also some abandoned and neglected plots in desperate need of renovation. These mostly represent places where people dump useless furniture parts, as well as other materials.

The further fate and outcome of »regulated allotment-keeping " in the City $\mathrm{Mu}$ nicipality of Ljubljana depends on the general attractiveness of the allotment areas. We should also mention some microelements of regulating such areas that are not to be neglected. Official acts will define the urban infrastructure of these areas as well as the corresponding lease relationships. It is imperative that the basic infrastructure (water distribution system, sewerage, sanitary fitting, the regulated disposal of waste, bicycle sheds, accessibility of parking places or bus stops) all be guaranteed for allotment-keepers. The Draft Ljubljana Zoning Implementation Plan (Dopolnjen osnutek Izvedbenega ...) also includes some other valid suggestions on planning, such as that the ratio between built-up areas and cultivating land areas should be as much as 30:70, the size of wooden garden sheds $2 \times 2 \mathrm{~m}$ at most, the size of individual plots between 50 and $100 \mathrm{~m}^{2}$ and separation of one garden from another should be facilitated by means of internal paths.

What is also important is the outlook of these areas, which should be more homogeneous internally (the same urban infrastructure - fences, sheds and boxes) and should be implemented into the urban area in a qualitatively more effective way. The »hiding " of allotments behind hedges, with the attendant effects both visual and auditory is to be welcomed (Pogačnik 2000). As a further important element of allotment-keeping is socializing, there should be places within the allotment area where gardeners can talk and socialize and educate one another about quality ways of growing vegetables (for example organically, or at least with suitable use of fertilizers and of phytopharmaceutical agents).

Allotment-keeping has been present in Ljubljana for many years. Now this activity has found a new challenge to compete against, namely the need for agreement to

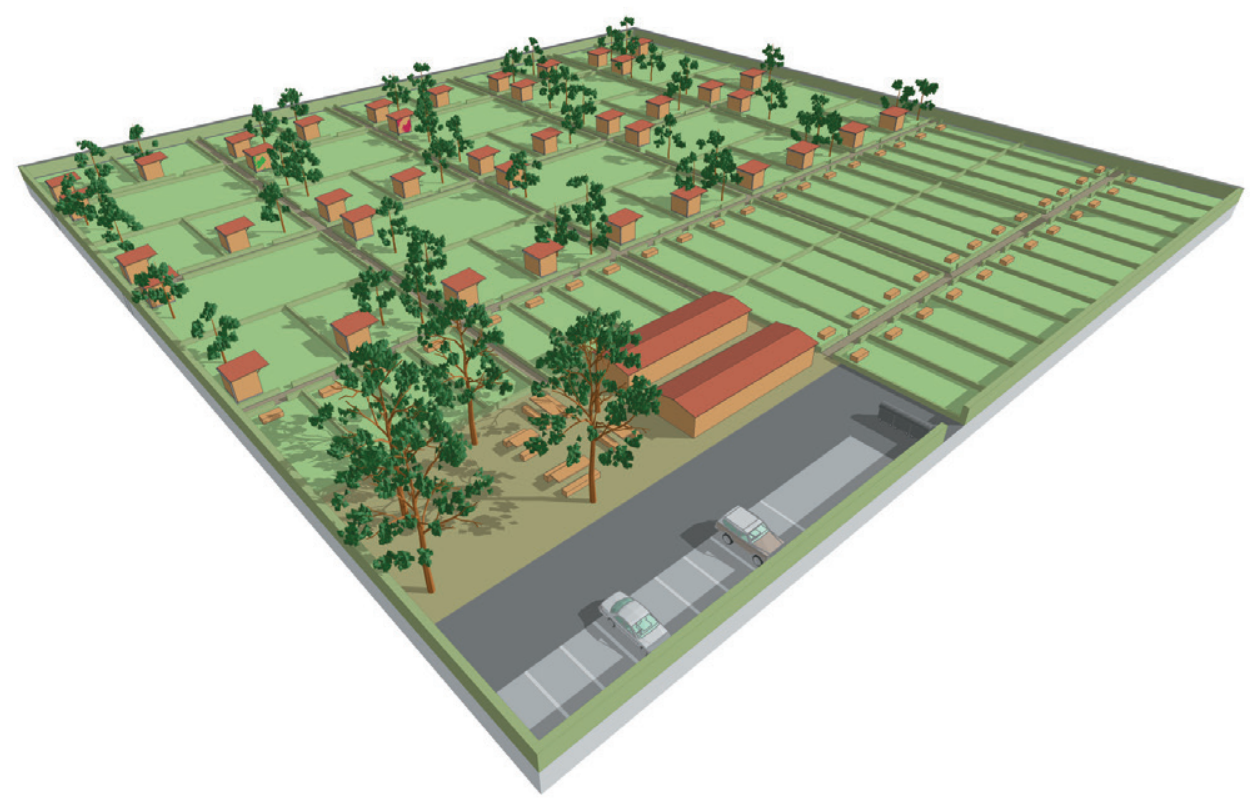

Figure 8. Illustration of a typical arrangement of an allotment covering one hectare. 
be obtained between the city authorities and allotment-holders themselves, that would favour both groups, as well as the population of Ljubljana as a whole.

\section{ACKNOWLEDGEMENTS}

This article is the result of a research project on allotment gardening in the City Municipality of Ljubljana as a source of pollution in the ground, in vegetables grown and in groundwater. That project was prepared by co-workers at the Anton Melik Geographical Institute of the Scientific Research Centre of the Slovenian Academy of Sciences and Arts, the Agricultural Institute of Slovenia and the public company Vodovod-Kanalizacija, d. o. o. We would like to thank the Office for Development Projects and Investments of the City Municipality of Ljubljana for financing the project.

\section{REFERENCES}

Bond van volkstuinders, Amsterdam (2009), $<$ http://www.bondvanvolkstuinders.nl/ index.php?menu=1\&stijl=1\&id=1>, accessed 17 March 2009.

Christl, I., Gultz, P. A., Kretzschmar, R. and Schulin, R. (2004), Umgang mit bodenbelastungen in familiengärten der stadt Zürich, Zürich, Institut für terrestrische Ökologie.

Daten und Fakten (2009), <http://www. stadtentwicklung.berlin.de/umwelt/stadtgruen/kleingaerten/de/daten_fakten/index.shtml>, accessed 16 March 2009.

DOF - digital orthophoto 2005 (2005), Ljubljana, Geodetska uprava Republike Slovenije.

Dopolnjen osnutek Strateškega prostorskega načrta MOL [Supplemented draft of the Strategic spatial plan of the City Municipality of Ljubljana], <https://urbanizem. ljubljana.si/NPA/SPN_ODLOK/SPN MOL_odlok.pdf>, accessed 15 April 2009.

Dopolnjen osnutek Izvedbenega prostorskega načrta MOL [Supplemented draft of the realization of the spatial plan of the City
Municipality of Ljubljana], <https://urbanizem.ljubljana.si/NPA/IPN ODLOK/ index.htm>, accessed 15 April 2009.

Goriup, Z. (1984), Planiranje in urejanje območij malih vrtov (vrtičkov) v Ljublja$n i$ [Planning and regulation of allotment garden areas in Ljubljana], Ljubljana: city's geography, Report, Ljubljana, Urbanistični inštitut Slovenije.

Jamnik, B., Smrekar, A. and Vrščaj, B. (2009), Vrtičkarstvo v Ljubljani [Allotment gardening in Ljubljana], Ljubljana, Geografija Slovenije 21.

Jernej, S. (2000), Mestna klima [City climate], in Gabrovec, M. and Orožen Adamič, M. (eds.), Ljubljana: geografija mesta [Ljubljana: city's geography], Ljubljana, Ljubljansko geografsko društvo, Založba ZRC.

Minister na slovesnosti ob podelitvi znaka evropske dediščine Plečnikovim Žalam [The Minister during the ceremony conferring the symbol of European heritage upon Plečnik's Žale], <http:// www.mk.gov.si/si/splosno/cns/novica/ browse/6/article/2130/5395/?\&tx ttnews \%5Byear\%5D $=2007 \&$ tx ttnews $\% 5$ Bmonth $\% 5 \mathrm{D}=02 \& \mathrm{cHash}=\mathrm{c} 1 \overline{9} 6405 \mathrm{f0}$ 8>, accessed 7 April 2009.

Pogačnik, A. (2000), Urbanistično planiranje [Urban planning], Ljubljana.

Rebernik, D. (2000), Morfološka zgradba [Morphological structure], in Gabrovec, M. and Orožen Adamič, M. (eds.), Ljubljana: geografija mesta [Ljubljana: city's geography]. Ljubljana, Ljubljansko geografsko društvo, Založba ZRC.

Simoneti, M. (2000), Narava $v$ mestu-med načrtovanim in spontanim [City nature - planning hand in hand with spontaneity], <http://www.dkas.si/?id=3,9,42>, accessed 17 June 2008.

Simoneti, M., Bevk, J., Pintar, M., Zupan, M., Gajšek, P., Golobič, M., Pleško, R., Bevk M. (1997), Usmeritve in pogoji za nadaljnji razvoj vrtičkarstva $v$ Ljubljani [Directives and conditions for further development of allotment-keeping in Ljubljana], Report, Ljubljana, Ljubljanski urbanistični zavod. 
Smit, J., Ratta, A. and Nasr, J. (1996), Urban agriculture: Food, jobs and sustainable cities, New York, United Nations Development Programme.

Smrekar, A., Kladnik, D. (2007), Zasebni vodnjaki in vrtine na območju Ljubljane [Private water wells and bores in the area of Ljubljana], Ljubljana, Georitem 4.
Vastl, N. (2000), Vrtičkarstvo [Plot gardening], Report, Ljubljana, Fakulteta za arhitekturo Univerze v Ljubljani.

Zimbler, R. L. (2001), Community Gardens on the Urban Land Use Planning Agen$d a$, Unpublished Master's Thesis, Chapel Hill, University of North Carolina. 